\title{
Fung Chi Ming, Reluctant Heroes. Rickshaw Pullers in Hong Kong and Canton, 1874-1954
}

Hong Kong, Hong Kong University Press, 2005, 220 p.

Xavier Paulès

\section{OpenEdition}

\section{Journals}

Édition électronique

URL : http://journals.openedition.org/chinaperspectives/1043

DOI : 10.4000/chinaperspectives. 1043

ISSN : 1996-4617

\section{Éditeur}

Centre d'étude français sur la Chine contemporaine

Édition imprimée

Date de publication : 1 juillet 2006

ISSN : 2070-3449

\section{Référence électronique}

Xavier Paulès, «Fung Chi Ming, Reluctant Heroes. Rickshaw Pullers in Hong Kong and Canton,

1874-1954 », China Perspectives [En ligne], 66 | July- August 2006, mis en ligne le 01 juin 2007, consulté le 10 décembre 2020. URL : http://journals.openedition.org/chinaperspectives/1043 ; DOI : https://doi.org/10.4000/chinaperspectives.1043

Ce document a été généré automatiquement le 10 décembre 2020.

(C) All rights reserved 


\title{
Fung Chi Ming, Reluctant Heroes. Rickshaw Pullers in Hong Kong and Canton, 1874-1954
}

\author{
Hong Kong, Hong Kong University Press, 2005, 220 p.
}

\author{
Xavier Paulès
}

\section{NOTE DE L'ÉDITEUR}

Translated from the French original by Michael Black

1 This book, which is taken from the thesis presented by Fung Chi Ming at the University of Hong Kong in 1996, deals principally with the collective action of rickshaw pullers in Hong Kong and Canton. The period chosen begins with their first appearance in Hong Kong, in early 1874, to 1954, which was the year of the last major social movement among rickshaw pullers in the British colony (even though the rickshaws only disappeared during the course of the following decade). The case of Canton fits within the course of those eighty years: the first rickshaws appeared there only in 1906, and disappeared prematurely, when the communists decided to forbid them after taking control of the city in 1949.

2 The rickshaw represents, in both cities, a kind of transition in transport services. At the beginning of the century, the rickshaw was largely instrumental in the disappearence of the palanquin. But several decades later, after the Second World War, buses and taxis (as well as the bicycle rickshaw in the case of Canton), took the rickshaw's place.

3 The early chapters of the book show how it would be a gross distortion to understand the rickshaw pullers as only being a social group subject to the domination of entrepreneurs who rented them the tools of their trade. Solidarity networks based on geographic and family origins, as well as dialects, made the reality more complex. They created specific and reciprocal obligations between rickshaw hirers and pullers, but also, horizontally, produced a segmentation of the pullers into subgroups with 
sometimes violent rivalries in the day-to-day exercise of their trade. When it came to collective action, these networks were both an advantage, as a catalyst of feelings of identity and of solidarity, and a major obstacle to the mobilisation of the rickshaw pullers as a whole.

The fate of the rickshaw pullers was even less decided in terms of a confrontation with the entrepreneurs who hired out the vehicles, as the authorities in both Hong Kong and Canton also had their say. The author concludes that generally speaking the British authorities were relatively oblivious to the fate of the rickshaw pullers, except for concerns with public order and the flow of traffic. This indifference was partly compensated for by the concern of some missionaries with the poverty of the rickshaw pullers. In contrast, the Guomindang and above all the Chinese Communist Party showed themselves to be very interested in the rickshaw pullers, to the extent that their work was considered to be highly representative of an imperialist system which exploited the Chinese people. In Canton, the communists gradually succeeded, after 1922, in organising the rickshaw pullers under the impetus of leaders who did not hesitate to share in their living conditions in order to win their confidence. The two most important among them were Shen Qing (1903-1928) and the son of Chen Duxiu, Chen Yannian (1898-1927). Their efforts led to the creation, in February 1926, of a single union, the Guangzhou shouchefu gonghui (the Canton Rickshaw Pullers Union), organised into four sections, which corresponded to differences in geographic and dialectal origins. The involvement of the rickshaw pullers in the revolutionary struggle reached its peak during the bloody episode of the Canton Commune of December 1927, in which a large number of them participated in arms.

Fung Chi Ming shows well the extremely varied character of the collective action of the rickshaw pullers in both cities during the period. It is unfortunately impossible to go into detail in the limited space of this review. It is however to be regretted that the author waits until the penultimate chapter (p. 155) to provide what is one of the keys to the negotiations between the entrepreneurs and the rickshaw pullers: the practice of dingshoufei. This was the rickshaw puller's recognised right, when he wished to stop working with a hirer, to negotiate the payment of a transfer fee from the rickshaw puller who was to be his successor. Dingshoufei, by preventing the hirers from resorting to hiring new rickshaw pullers as substitutes for strikers, was thus a considerable advantage for the latter.

6 Reaching the end of the book, one has not learned much about the rickshaw pullers as individuals. The only detail provided concerns the geographic origins of the rickshaw pullers and an interesting description of their living and working conditions in Chapter 2. One is therefore left somewhat unsatisfied. The book amounts to only 180 pages, not including the appendices, and the gap could certainly have been filled as the sources for the task do exist. The Guangzhou nianjian from 1935, for example, published the statistics (age, family status, level of education) from a study of five thousand rickshaw pullers carried out in November 1933. This source is familiar to Fung Chi Ming, who quotes it in a footnote on p. 97. It would have been useful to make fuller use of it. The ten interviews carried out by the author in 1990-1991, while full of information, could certainly also have provided interesting facts about the question of the personal careers of rickshaw pullers, which is hardly touched on. One would like to know, in particular, if the job was merely a transitional occupation which they sought to abandon as soon as possible, or if the majority of them made it into a permanent 
career. This is far from insignificant when it comes to a better understanding of the difficulties of collective organisation.

7 The errors I found in particular concern Chapter 5, in which the reminders dealing with the political situation in Canton in the years between 1910 and 1920 do not distinguish themselves by their rigorousness. It must be said that this is a highly complex subject which does not lend itself at all easily to synthesis. Nevertheless, it was in 1913 and not 1915 that Long Jiguang took control of Guangdong province (p. 77). Moreover, the revolt of the militarists Liu Zhenhuan and Yang Ximin at the beginning of June 1925 was put down by troops loyal to the Guomindang during the same month, and not, as the author states, "at the end of the year" (p. 84). Also, contrary to what is stated on $p$. 31 , the game of chance called fantan is not played with a dice.

Despite these criticisms, it must be emphasised that Reluctant Heroes is a solid and useful contribution to the social history of Hong Kong and of Canton, and that the author has carried off one of the challenges of his book, which was to link up in a pertinent fashion the history of two profoundly different cities. Lastly let us point out that this book is destined to be a milestone for another reason. It is the first of a series of monographs devoted to Hong Kong, whose publication is announced by the University of Hong Kong Press, thanks to the support of the Royal Asiatic Society. 